\title{
EMPLOYING AGENT-BASED SIMULATION TO UNDERSTAND THE BEHAVIOR OF DOMESTIC BEEF-CATTLE PRODUCTION
}

\author{
Andre R Daud ${ }^{1}$, Utomo S Putro², Dhanan S Utomo² \\ ${ }^{1}$ Fak. Peternakan Universitas Padjadjaran, \\ ${ }^{2}$ Sekolah Bisnis dan Manajemen Institut Teknologi Bandung \\ ardaud@unpad.ac.id
}

\begin{abstract}
The purpose of this paper is mainly to understand the behavior of domestic beef production through estimating the dynamics of domestic cattle population. Agent based model (ABM) approach and its simulation is employed in this study. The main reason to use this approach is on its capability to accommodate the complexity given existing characteristics in cattle and beef production system. Based on the findings, agent-based model approach performs well in explaining the emergent behavior for agricultural production system, especially cattle production system. Several important implications have also been drawn from this study. Therefore, this study has generated several new insights that will be advantages for further studies.

Keyword: beef cattle, population dynamics, agent based model, simulation.

\section{PENGGUNAAN SIMULASI BERBASIS AGEN UNTUK MEMAHAMI PRILAKU PRODUKSI SAPI POTONG}

Kajian ini bertujuan untuk memahami perilaku produksi daging sapi di Indonesia yang diperoleh berdasarkan estimasi dinamika populasi sapi potong lokal. Model berbasis agen (agent-based model) dan simulasinya digunakan sebagai pendekatan utama dalam memperkirakan dinamika populasi tersebut. Penggunaan model ini didasarkan atas kemampuannya untuk mengakomodasi kompleksitas karakter produksi sapi potong dan daging sapi yang terdapat pada saat ini. Berdasarkan hasil kajian, pendekatan model berbasis agen dapat dengan baik menggambarkan dan menerangkan perilaku sistem produksi sapi potong sesuai dengan kondisi aktualnya. Beberapa faktor penting di dalam sistem produksi dan implikasinya terhadap kebijakan pengembangan usaha sapi potong dapat dihasilkan melalui model ini dan simulasinya.
\end{abstract}

Kata kunci: daging sapi, sapi potong, dinamika populasi, model berbasis agen, simulasi.

\section{Introduction}

The trend of rising import rate on beef and cattle is evident in Indonesia. Facts have shown that to fulfill the domestic demand of beef, Indonesia has to rely on international supply. The quantity of import, both for cattle and beef, is high if compared to other countries in Asia. Meat and Livestock Australia (MLA) had issued a report on their cattle and beef export to Indonesia in 2011. In that period and previous year, Indonesia had imported cattle as sixty to seventy thousand heads. This level of import had been accompanied by the import of beef and beef product. MLA also recorded that in the current year, Indonesia is capable to import as seventy thousand tons of beef a year, and around twenty thousand tons of edible offal to satisfy its domestic demand. Many published data show that the rate of Indonesia's import of cattle and beef can be as high as six to nine percent a year in the future.
Incapability of domestic beef production is often considered as the major reason for the increasinglevel ofimportation. Thus, the current livestock policies are mainly aimed to expand the capacity to produce beef domestically. In this context, it is important to understand the implication of current cattle population for beef production. As a biological process, the level and the behavior of beef production are larg ely determined by the characteristics of given production system. Based on this logic, any instrument that able to describe the output from current population is required to determine some appropriate livestock policies. Principally, the size and structure of cattle population is the basic information that is required to determine the level or the behavior of particular beef production. Once they are known, one can generate any estimation and prediction about the capacity of beef production in given certain period. 
However, in the present time, there are limited numbers of work that address the cattle population aspect as the determinants of beef production behavior. This may be driven by the availability of population data, especially in many developed countries. If the data is readily available, production behavior does not have to be estimated, on the contrary, it is counted. The problem is aroused when for any reason there is lack of data, like mostly in the developing countries. The poor infrastructure for agricultural data collection results on the very low availability of important data. In this case, to determine the level or the behavior of beef production, one has to rely on the estimation from given cattle population and the characteristics of production system.

Therefore, the purpose of this paper is mainly to estimate the behavior of beef production from given structure of cattle population and production system. Specifically, there are two objectives that this paper needs to achieve; that is to: (i) assess the dynamics of cattle population given hypothetical population structure; and (ii) estimate the behavior of beef production from given structure of cattle population. Agent based model (ABM) approach then is exercised to generate such behavior on the beef production. The main reason to use the approach is on the model capability to accommodate the complexity given by the characteristic along the beef production. This approach is expected to generate some new insights that is able to contribute in determining the behavior of domestic beef production.

\section{Literature Review}

As stated previously, there are limited numbers of academic work that specifically derived some beef production behaviors from given cattle population characteristics. Especially in developed countries, the large scale censuses for obtaining current data on the level of beef production are conducted regularly. For example, USDA in United States conducts large scale cattle census every five years to provide the detail picture of US farm and ranches and also the farmers who operate them (USDA, 2013). In European countries, similar census is performed once in every ten years, but it is complemented by the intermediate survey in every year (Eurostat, 2013). Given the capability to perform such survey and census in determining the level of beef production, one does not need any estimation method. Nevertheless, the estimation of beef production behavior is common in the developing countries. Various works employ several approaches to estimate and predict the dynamic of both cattle and beef production in their respective countries. Several related work focused on the issues of cattle population dynamics and beef production exist in the literature. The two kind of works be presented as follows. We will begin first with previous work on cattle population dynamics.

Hermans, Udo and Dawood (1989) have studied the cattle dynamics and their implications in Bangladesh. They used statistical approach in utilizing secondary data to estimate the structure of cattle population in their respective study area. Rosen et al (1993) had constructed the model of cattle cycles based upon rational breeding stock inventory decisions in the presence of gestation and maturation delays between production and consumption. Their work was based on a structural econometric timeseries estimates over the 1875-1990 period. Tulachan, Partap and Maki-Hokkonen (2000) generally studied the development of livestock sector development in Asia, Africa and South Africa. In small part of their work, they estimated the number of cattle by employing statistical method upon cattle asset owned by household. Desta and Coppock (2002) have studied the cattle population dynamics in the Kenya. This study put emphasis on the social-economic aspect of cattle production. They estimated the size of cattle population descriptively based upon the trend and the stocking rate. Bebe et al (2003) studied the implication of herd dynamics of smallholder dairy in Kenya. In a part of their work, they estimated the cattle population dynamics using the general linear model on statistical method to determine the current number 
of cattle. Recently, in Indonesia, Sumadi et al (2009) have studied the some cattle breed population distribution, and estimated the output. They used descriptive statistic approach to estimate the size of population and the output from given structure of population.

The work of Buffer \& Freebairn (1975) and Ospina \& Shumway (1979) are few first works that incorporating the dynamics of population to the beef supply. In both work, authors employ classical simultaneous equations econometric approach to estimate the beef supply response in United States. In general, the beef supply model is including price, import and seasonal effect as determinant for beef supply behavior. Moreover, Shonkwiller \& Hinckley (1985) generated a generalized supply response and factor demand model applied to feeder cattle market. In general, they employed statistical method, i.e. partial adjustment adaptive expectation (RATEX model) from Nerlove, to conduct some test on changes of beef supply behavior. These previous works then complemented by Aadland et al (2000) who investigated the response of beef cattle producers to changes in the price of cattle in United States for the long-term period. They used large longitudinal data (from 19301997) to be fit in a simultaneous equations econometric approach.

In another work, Sartorius et al (2002) had studied the potential beef supply in Southern African region. They incorporated supply response, demand side and stocks in their model. To do the estimate, time-series analysis was employed to generate coefficient of estimates on beef supply response. In Canada, Mbaga \& Coyle (2003) had used autoregressive distributed lag model to estimate the response of beef industry. They put more emphasis on the factor of risk and price variance within the industry. Accordingly, Griffith et al (2004) had conducted similar approach for beef industry in Australia. They expanded their work on the performance of feedlot business in response to economic environment changes. A multi-equation econometric approach was employed to study the related issues. Recently,
Anatonova \& Zeller (2007) had studied beef supply response in Russia. They put more emphasis on the implication of European agricultural sector development polices to Russia beef sector. To conduct such study, an econometric time-series analysis to estimate the beef response. Rezitis \& Stavropoulos (2008) had conducted similar work in the case of Greek. To expand previous work, they put more emphasis on the price volatility, and used an econometric approach, i.e. GARCH model to estimate the behavior of beef supply.

As can be observed, most of the previous work employs statistical approach to perform estimation on the cattle population, or beef production. From the authors, the main limitation in doing such estimation is the statistical properties that they employed. As most of them employed the linear model of statistical method, the dynamics of the cattle population, and the beef production, were missing in their studies. Their findings then suggest the use of more flexible methods in estimating the population or the behavior of beef production.

\section{Methodological review}

Agent based modeling approach for agricultural production system. For a basic understanding on agent-based approach, Macal and North (2010) have suggested that a typical of agent-based model (ABM) comprises three basic elements: (i) a set of agents with their attributes and behaviors; (ii) a set of agent relationship and methods of interaction; and (iii) the agent's environment. ABM thus models where individuals or agents are described as unique and autonomous entities that usually interact with each other and their environment locally (Railsback \& Grimm, 2010). Agents may be any entity that pursues a certain goal. This implies that agents usually are different from each other in such characteristics and interactions. This also implies that agents act independently of each other and pursue their own objective. Therefore, agents use adaptive behavior where they adjust their behavior to the current states of themselves, of other agents and of their environment. 
Furthermore, Railsback \& Grimm (2010) suggest that $A B M$ provide a method to address problems that concern emergencecomplexity. The emergence is system dynamics that arise from how the systems individual components interact with and respond to each other and their environment. The possibility for ABM to address such a problem comes from the model's ability to work across level, i.e. working vice versa between individual and its system. In other word, ABM focus on modeling behavior of agents and, at the same time, observing and understanding the behavior of the system made up by the agent.

In agricultural research, especially in animal-farming field, the use of ABM approach to understand individuals and the whole system of agriculture is relatively new. Although agricultural field has its own approach to understand the system, i.e. biophysical approach, it is still limited and constrained by existence of the complexity in the agricultural system. Indeed, agricultural production is one of system that is very complex. To provide its complex system, we illustrate a generic form of agricultural production system in this next figure.

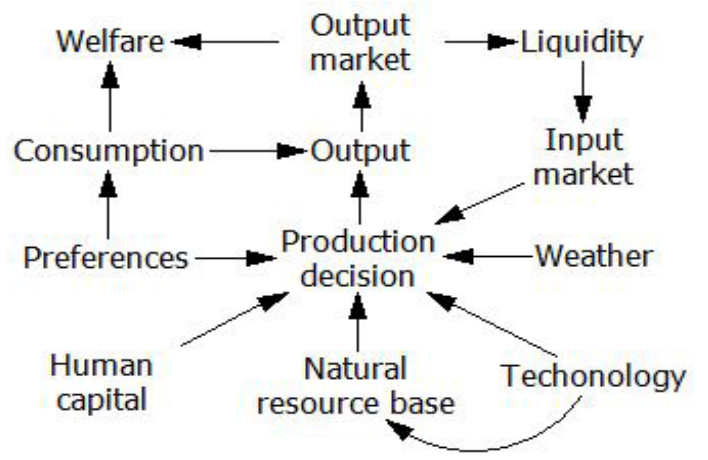

Fig.1. Generic system (Bebe et.al, 2003)

Agricultural production system, as illustrated in the figure above, present all of agents, interactions and environment defined previously by Macal \& North (2010) and Railsback \& Grimm (2010). As we can observe, the agricultural production system comprises many agents whom having many interactions within their agricultural environment. Consider animal farming system; millions of farmers - as the most important agent in the system - with their heterogeneous characteristics and attributes, have their own autonomous to decide how much cattle they should keep, to whom they should sell their cattle, on what price in where market which avoiding risks, to satisfy their given family-household objectives, under environment uncertainty. Given this complexity, similar situation applies for other agents in this animal-farming system. Ideally, ABM approach should be able to solve problems faced by animal farming society, especially for beef and cattle production system. Currently, all can accept that our level of production on cattle and beef is very low. Then, many believe this as the biggest problem for the society to encounter. However, in fact, many others certain that this situation is one of the emergent phenomena aroused from our current system of cattle and beef production. The problems itself lie somewhere behind all agents, interactions and environment within the system. Therefore, to deal with the low-level production of cattle and beef, a thorough understanding on how the individuals and the system exactly behave is one of the urgent necessities. Here is the space for $\mathrm{ABM}$ approach to provide these necessaries understanding of the system.

\section{METHODOLOGY}

Agent-based model approach is employed to model the beef-cattle production system. As previously discussed, there are many advantages using this approach especially for the biological industry, i.e. beef and cattle production system. However, there are several steps in exercising this approach. The steps comprise of formulating the questions, assembling the hyphotheses, choosing the model structure, implementing or executing the model, and analyze the model (Railsback \& Grimm, 2010). The questions addressed by building this model are evidently clear. For the first question, this model attempts to illustrate the population dynamics, or the continual changes on cattle number within its population. Given the biological characteristics of the cattle, one can be sure that the size of the population is always in changes. Secondly, the fluctuation 
of beef production, or beef supply, is also one of the main interest. Given their beef production characteristics, then the level of beef supply is hypothesized to be inconsistent and heavily fluctuated. The general structure of beef-cattle model is proposed in Figure 2. However, the model built in this study is only a small part compared to the whole model as presented on Figure 1. For some reasons, building a complete model of beef and cattle production system is yet possible. This also serves as the main limitation of the study. Therefore, only some basic structure and components are considered in building the beef-cattle agent-based model.

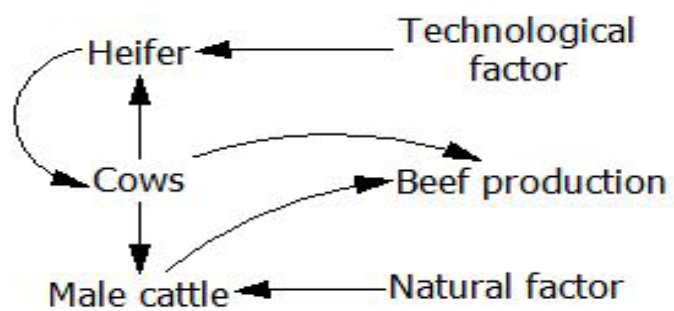

Fig.2. General structure of beef-cattle model

Table.1. Model components and assumptions

Interactions/Environment
Agents
Cow is mature female cattle. The cows reach its maturity at around $15-24$
months old. The behavior of cows, in this model, is determined by
biological characteristics (ie. mating period, pregnancy period, weaning /
post-birth period). Mating period starts when the cows reach average 18
months old, the pregnancy period is 9 months period, and the post-birth
period occurs in 3 months period. Sex ratio also represents the biological
characteristic of cow. Sex-ratio is the probability for particular cow to have
male or female in one birth. In this model, the $40 \%$ probability for female
is applied. For the beef industry, male cattle are more preferred. The
technological factor is represented by the service per conception of
artificial insemination (Al). It is common that two service of insemination
will give the cows a pregnancy.
Heifer is young female cattle with the age between 9 months to 15 months
Heifer old. In this model, heifers are not explicitly presented. The heifers cycle
then become a part of cows' cycle ofproduction.
Bull is mature male cattle. Similarly, the bull reaches its maturity at
around 15 months old. In this model, slaughtered bull is the main source of
beef production. The behavior of bulls, in this model, is determined also
by biological characteristics (i.e. the ability to gain additional weight in
given circumstance). The ability to gain an additional weight is affected by
the environment. In this model, environmental factor is represented by the
seasonal climate. In wet season, when feed are abundance, a bull can gain
$15 \mathrm{~kg}$ additional gain per month on average. On the contrary, in the dry
season, bull can only gain as 7.5 kgs additional weight permonth.
Beef production is resulted from slaughtered bull and cows. The bull is
assumed to be slaughtered at the age of 30 month old, while the cows are
slaughtered when itcomes at 60 months old. In fact, there is no single rule
Beef for bull to be slaughtered, however in this model; bull with more than 2
years old is assumed to be the case. The beef produced by a single bull is
assumed to be between $180 \mathrm{kgs}$ and 225 kgs. The assumption applies
similarly for the slaughteredcows.

In this beef-cattle agent-based model, there are three agents complemented by their interaction and their encountered environment. The agents are mostly the animal (cattle) in various type and characteristic. The interactions, thus, occur between those three types of cattle. The environment finally embedded to those agents and their interaction. Finally, the emergence properties, or the output, from the current model is the behavior beef production. For more clarity, the assumptions that is used on the agents, interaction and environment will be described more detail in the following table.

Having the model structure to be specified, and the components to be defined, the model is implemented through simulating the operational model. To simulate the model, a supporting system called NetLogo version 5.04 is employed. Thus, the operational model of all agents, interactions and environment entered to the system can be illustrated on this next Figure 3 , and this then is translated to the NetLogo algorithms.

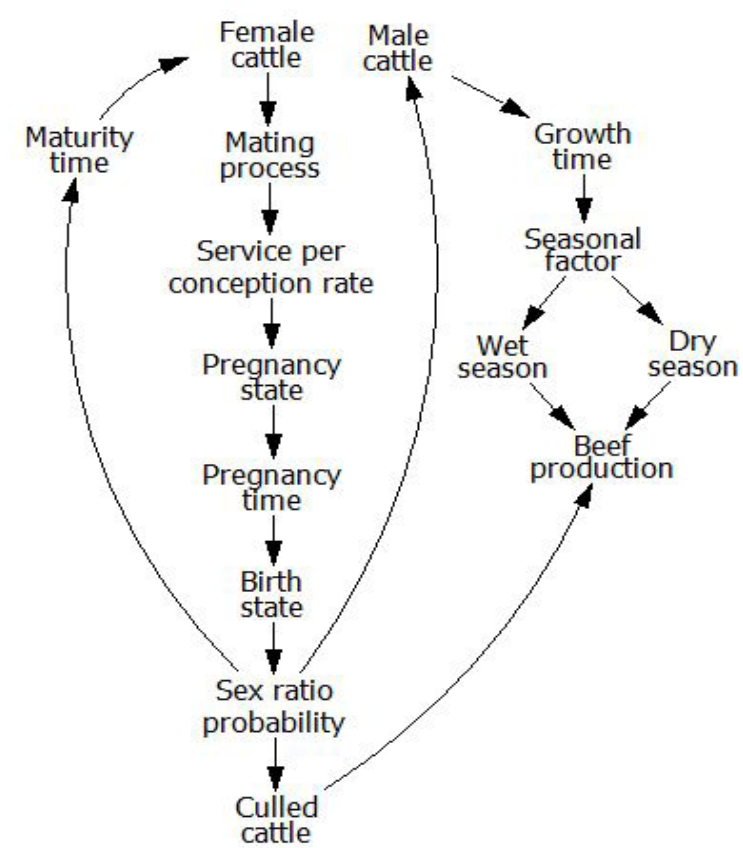

Fig.3. Operational beef-cattle model algorithm

Substantially, current beef cattle model comprises of processes and decisions. The processes that occur in both female cows and male bull are essentially biological processes, i.e. the process of mating, pregnancy, birth, or growth and beef production in male bull processes. There also exists components 
that play as determinant of those process. This model includes service-conception rate, sex-ratio probability, and the rainy-dry season that will affect the whole process. Later, these determining components can be regarded as entry point for intervention in perturbing or leveraging the model. In brief, this model attempts to illustrate and develop the relationship between the cattle biological process and the behavior of beef production as the output of the model. Moreover, one can observe that the level of beef production is also determined by the state and behavior of determining components.

The model is being analyzed after it is implemented and simulated by the system. In the context of this study, there are two methods used to analyze the model based on the questions that will be addressed. Essentially, the analysis aims to test whether the structure and components included in the model are fit and correctly specified. For the first question, the population dynamics generated by the model is then tested against the actual cattle population structure. Fortunately, the data on actual cattle population is readily available from the government. This data are resulted from the Indonesia Livestock Census conducted in 2012. On the contrary, the data for comparing the behavior of beef production is not readily available, thus alternatively, the model has to be analyzed by other method. We prefer to employ some simple statistical approach to test whether the model is capable to generate any output in a consistent manner. To do such test, a comparison on coefficient of variation (CV) between successive outputs generated by each model simulation is employed. The $\mathrm{CV}$ formula can be written as:

Where SD stands for the standard deviation of outputs, and $\mathrm{X}$ bar refers to the mean of each output from single model execution. Since the value of $\mathrm{CV}$ can be obtained, then its value comparison between outputs can be exercised.

There are many limitations in this beef-cattle model. This model plays only as a small subsystem from the whole beef production system (see Fig.1 and Fig.2). From the perspective of agents, many more should be included in this model. Farmer is the most important agent in this kind of model, but they are excluded. In fact, farmers have large share upon the available decisionmaking process that related to the beef-cattle production behavior. However, for now, the current model put more emphasis indeed on the biological and physical characteristics of beef and cattle, and then the farmers will be main consideration in the next modelbuilding project. Limitations also exist in defining interactions and environment in this model. There are many interactions in beef-cattle production excluded, i.e. the interaction between farmers and other actors in beef business, domestic market and international market, or even the interaction with the government. The environment or circumstances are also considered incomplete. Currently, the model encounters environment factor only through the effect of seasonal climate. In fact, in the real world, beef production encounters many circumstances, i.e. social environment, organizational or institutional environment, and so forth. All of possible environment and circumstances within beef-cattle production system will be accommodated in the next model-building opportunities.

\section{RESULT AND DISCUSSION}

In exercising the model, we set one single simulation-time to represent a month in the real time. In every simulation, around 1000 times-simulations is executing. These times-simulation can represent a period consisted of 80 years in real time. The simulation, then, is performed for twelve times to obtain the result.

Having simulation on the model, one can capture the dynamics occurred in cattle population. Figure 4 illustrates the dynamics behavior of the cattle population in long term. Given the biological characteristics of the cattle, especially on the value of service per conception (SC), the size of the population will always be varying, although the number of male and female cattle shares common fluctuation pattern. The other biological characteristic, i.e. the sex-ratio probability, amplifies the fluctuation of male and female 
cattle. As one can see, more number of female cattle will be experienced in particular time, while it will be less than male cattle in other times. From this dynamics pattern of population, we can confidently state that without any intervention on the production system, the cattle population will be unstable in the long term. Based on the specification of the model, the various form of intervention to leverage beef production should be better addressed to the determinant components in the model, i.e. the value of SC and the sexratio.

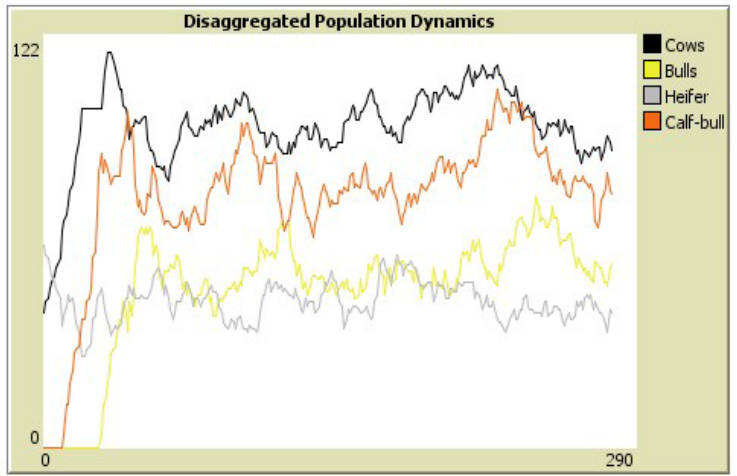

Fig.4. One of single turn simulation of cattle population dynamics

However, the phenomena captured by this model have to be justified against real phenomena. Although there are no longitudinal data for cattle population available, the current real structure of cattle population can be accepted as result from its long-term dynamics. This study relies on those data as a reference to compare the output from proposed model. The comparison between real and simulated population structure is listed in Table 2.

Table.2. The actual and generated pattern of population structure

\begin{tabular}{ccccccc}
\hline \multirow{4}{*}{ No } & \multicolumn{3}{c}{ Female } & \multicolumn{3}{c}{ Male } \\
& {$[1]$} & {$[1 \mathrm{a}]$} & {$[1 \mathrm{~b}]$} & {$[2]$} & {$[2 \mathrm{a}]$} & {$[2 \mathrm{~b}]$} \\
\hline R & 68.1 & 66.1 & 33.9 & 31.9 & 30.8 & 69.2 \\
1 & 52.3 & 69.1 & 30.9 & 47.7 & 39.3 & 60.7 \\
2 & 52.6 & 68.5 & 31.5 & 47.4 & 39.9 & 60.1 \\
3 & 52.9 & 68.5 & 31.5 & 47.1 & 39.5 & 60.5 \\
4 & 52.1 & 69.0 & 31.0 & 47.9 & 39.4 & 60.6 \\
5 & 52.9 & 68.8 & 31.2 & 47.1 & 39.3 & 60.7 \\
6 & 52.2 & 68.8 & 31.3 & 47.8 & 39.3 & 60.7 \\
7 & 52.2 & 68.8 & 31.2 & 47.8 & 39.5 & 60.5 \\
8 & 52.0 & 69.5 & 30.5 & 48.0 & 39.7 & 60.3 \\
9 & 52.7 & 68.3 & 31.7 & 47.3 & 39.8 & 60.2 \\
10 & 52.6 & 68.8 & 31.2 & 47.4 & 39.6 & 60.4 \\
11 & 53.0 & 68.6 & 31.4 & 47.0 & 39.7 & 60.3 \\
12 & 53.1 & 68.8 & 31.2 & 46.9 & 39.2 & 60.8 \\
\hline
\end{tabular}

For Table 2, $\mathrm{R}$ stands for reference which is the actual data; [1] and [2] are the percentage of total female and male cattle to the total population $(1+2=$ total population). [1a] \&[1b] and [2a] \& [2b] are the percentage of mature and young cattle respectively $(1 \mathrm{a}+1 \mathrm{~b}=1 \mid 2 \mathrm{a}+2 \mathrm{~b}=2)$.

Currently, the size of cattle population in Indonesia is about 14 million heads of cattle. In the given population, $68.1 \%$ of them are female cattle at various levels of age, i.e. $66.1 \%$ mature female (cows at more than 18 months) and $33.9 \%$ for young female cattle (heifers). The " $R$ " row in Table 2 presents the percentage for male cow as well. Given the actual data as reference, beef-cattle model that built in this study has generated relatively different pattern of population structure. As column [1] and [2] represent the total number of female and male cattle, one can observe that model has generated underestimated number for female, while it overestimates the number of total male cattle. For example, the percentage of actual female cattle from total cattle population is around $68 \%$, while the model generates the percentage in range of $52-53 \%$ from total population. Similarly, the model also overestimates the number of male cattle percentage at $46-48 \%$, while the actual percentage is only around $32 \%$. These differences can also be observed on the more disaggregated age-type male cattle (column [2a] and [2b]). There are at least 9\% differences from the actual data on each agetype of male cattle.

However, the model is likely able to generate better estimation for mature female (cows) and young female cattle (heifers) within total female population, as shown in column [1a] and [1b]. Having referred to the actual data, there is only slight difference on percentage for these two type of cattle. The percentage of current cows' actual number is around $66 \%$ from the total number of female cattle, while the model estimates a range of $68-69 \%$ for this type of cattle. It is also true for the heifers (and younger cattle) that occupy a percentage of $30-31 \%$ while 
the actual data show a percentage of $34 \%$. In two types of female cattle, there is only $2-3 \%$ differences in cattle number compared with the actual number.

Having compared the actual population structure with generated structure of population, it is rather difficult to justify robustness of beef-cattle model due to existence of several differences, especially for male cattle population. There may two reasons that can explain the differences generated by the model. For the first, the incomplete structure specifications are evident on this model. As stated previously, this model only includes small number of components compared with the complete one. Secondly, there is possibility in using incorrect assumptions for this model. In the case of mature and young male cattle, it is suspected that the model uses less appropriate age assumption. We can observe it from column [2a] and [2b] in Table 2 respectively. Due to different definition of age, the simulation will result in overestimation number for mature male cattle and underestimation for younger male. But if we can re-specify $9 \%$ number of mature cattle to the group of younger one, then the model is likely to able to generate relatively similar percentage of male population as in the actual data. Therefore, different population patterns generated by beef-cattle model are able to be justified. One can then be certain that the differences are only owing to the absolute number of cattle, not from the structure.

Given the acknowledged structure of cattle population, the behavior of beef production can be observed. Figure 5 presents the pattern, or emergent behavior, of beef production corresponded with the existing number in cattle population.

As the dynamics in population, beef production exhibits a similar pattern. In a certain period, high level of beef production can be achieved, while in other of time sharply decline in production can be experienced.

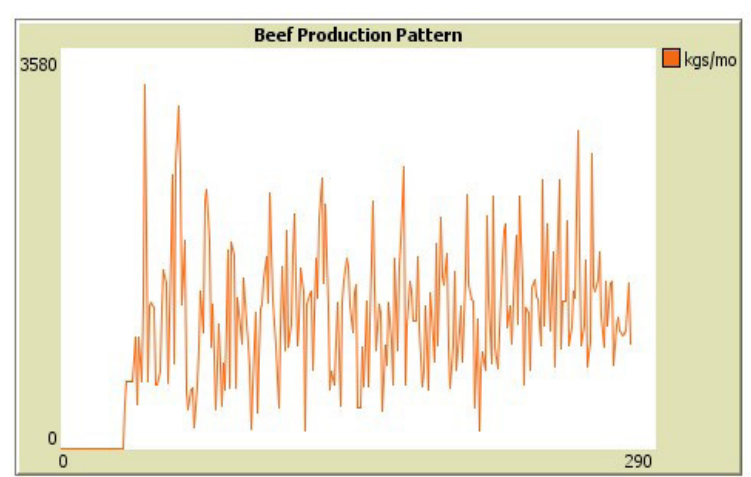

Fig.5. The behavior of beef production

It can be also observed from the pattern that beef production tend to be stagnant overtime, regardless cattle population dynamics. However, the pattern is also be able to show the possible maximum level that our beef production can achieve.

Tabel.3. The variation of beef production

\begin{tabular}{|c|c|c|c|}
\hline No & $\begin{array}{c}\text { Mean (kgs/ } \\
\text { month) }\end{array}$ & SD (kgs) & CV (\%) \\
\hline 1 & 1157.93 & 575.65 & 49.71 \\
\hline 2 & 1270.25 & 594.72 & 46.82 \\
\hline 3 & 1201.37 & 559.21 & 46.55 \\
\hline 4 & 1760.99 & 763.53 & 43.36 \\
\hline 5 & 1345.90 & 619.05 & 46.00 \\
\hline 6 & 2226.48 & 1155.58 & 51.90 \\
\hline 7 & 1248.52 & 600.54 & 48.10 \\
\hline 8 & 1512.36 & 675.17 & 44.64 \\
\hline 9 & 1602.51 & 707.93 & 44.18 \\
\hline 10 & 2014.60 & 893.61 & 44.36 \\
\hline 11 & 1525.68 & 670.28 & 43.93 \\
\hline 12 & 1900.44 & 817.92 & 43.04 \\
\hline
\end{tabular}

For Table 3, mean stands for the average of beef production in one month; SD stands for standard deviation given some series of data generated by simulation; CV stands for respectively coefficient of variation.

As previously stated, there are no data available to benchmark the emergence pattern to the actual pattern of beef production. In published livestock statistics, it is evident that quantity of beef production is roughly estimated from given stock of bulls in one point of time, and excluded the number of slaughtered cows. One believes that such method of estimation is potentially biased, as the cattle population experiences its dynamics. Thus, the consistency of model in generating the emergence behavior of beef 
production is examined through it variation. The Table 3 lists various value of variation coefficient for each simulation.

Two findings can be drawn from the list of variation coefficient that shown in the table above. First, from modeling perspective, the beef-cattle model is likely able to generate a series of consistent calculation, that is indicated by existing slight differences between all calculated coefficients. The coefficient of variation is roughly ranging from $43-51 \%$ in each simulation. This indicates that every simulation is substantially similar in term of generated output.

The second finding is the main importance of this study. As to determine the behavior of beef production given the existing cattle population, one can observe that the level of beef production, or supply, is heavily fluctuating. Beside from the coefficients, this fluctuation is obvious from the physical data generated from simulation. The value of standard deviation can show how high the fluctuation is taking into account. On average, the level of fluctuation is nearly half of given estimated production level. It indicates that the level of beef supplied to the market can vary widely in every time production period. From this emerged pattern, one obvious implication is the need to stabilize the level of beef production to ensure the quantity supplied to the market. In addition, some safety stock mechanisms are required to reduce any impact from production fluctuation.

\section{CONCLUSION}

Basedonthefindings, itcanbeconcluded that in general agent-based model approach performs well in explaining the emergent behavior for agricultural production system, especially cattle production system. Several important phenomenon in cattle production system, e.g. heavily fluctuated and varied in both cattle and beef production, have been captured. The implications resulting from the situations for any intervention or policies have also been drawn based on related findings. ABM approach has indeed provide us method to gain better understanding on animal-farming system, especially on partially examining cattle population dynamics and its corresponding levels of beef production. Due to limitations, such study, and the approach, can be expanded to include more agents and interactions within the system. However, our study has likely been able to generate several new insights on agricultural production modeling practice that can serve as guidelines for other further studies.

\section{REFERENCES}

Aadland, D., Bailey, D., Feng, S. 2000. A theoretical and empirical investigation of supply response in the US beef cattle industry. Paper presented at Annual meeting American Agricultural Economics Association, Iowa

Antonova, M., Zeller, M. 2007. A time-series analysis of the beef supply response in Russia: implication for agricultural sector development policies. Paper presented at the Joint IAAE - 104th EAAE Seminar

Bebe, B.O., Udo, H.M.J., Rowlands, G.J., Thorpe, W. 2003. Smallholder dairy systems in the Kenya highlands: breed preferences and breeding practices. Livestock Production Science, Num.82, pp.211-221

Benjamin, C. 2002. Measuring the effects of alternative support policy instruments on beef supply. Paper presented at the Xth EAAE Congress, Zaragoza Spain, August 2002.

Buffier, B.D., Freebairn, J.W. 1975. Response function estimates for lot fed beef. Review of Marketing and Agricultural Economics, Vol 43, Num 1, pp. 40-51

Desta, S., Coppock, D.L. 2002. Cattle population dynamics in the southern Ethiopian rangeland 1980-97. Journal Range Management, Num 55, pp. 439-451

Eurostat. 2013. Agricultural censuses in the Europe. Available at http://epp. eurostat.ec.europa.eu. Accessed at May 19th 2013 
Griffith, G.R., Coddington, A., Murdoch, S. 2004. Beef feedlot supply response in Australia. Agribusiness Review, Num 12

Hermans, C., Udo, H.M.J., Dawood, F. 1989. Cattle dynamics and their implication in Pabna District Bangladesh. Agricultural System, num29, pp. 371-384

Macal, C.M., North, M.J. 2010. Tutorial on agent-based modeling and simulation. Journal of Simulation, Num 4, pp. 151-162

Mbaga, M., Coyle, B.T. 2003. Beef supply response under uncertainty: an autoregressive distributed lag model. Journal of Agricultural and Resource Economics, vol 28, num 3, pp. 519-539

Ospina, E., Shumway, C.R. 1979. Disaggregated analysis of short-run beef supply response. Western Journal of Agricultural Economics, pp. 43-60

Railsback, S., Grimm, V. 2010. Agent-Based and Individual-Based Modeling. Princeton University Press

Rezitis, A.N., Stavropoulos, K.S. 2008. Greek beef supply response and price volatility under cap reform. Paper presented at the 12th EAAE Congress

Rosen, S., Murphy, K.M., Scheinkman, J.A. 1993. Cattle cycles. NBER Working Paper No.W4403. Available at: http:// ssrn.com/abstract $=227312$. Accessed at May 19th 2013

Sartorius, H.J.B., Renen, E., Kirsten, J.F. 2002. Supply response, demand and stocks for southern African beef. Working Paper 98-01. Dept of Agricultural Economics, Extension and Rural Development, University of Pretoria

Shonkwiler, J.S., Hinckley, S. 1985. A generalized supply response / factor demand model and its application to the feeder cattle market. Western Journal of Agricultural Economics, pp. $245-253$

Sumadi, Ngadiyono, N., Wibowo, L.R., Sulastri. 2009. Distribution of population and output estimation of some cattle breeds at Bawang Subdistrict Banjarnegara Regency Central Java Province. Paper presented at The 1st International Seminar on Animal Insdustry

Tulachan, M.P., Partap, T., Maki-Hokkonen, J. 2000. Livestock in the mountains and highlands of Asia, Africa and South America: an overview of research and development issues and challenges. In Tulachan, M.P., Saleem, M.A.A., Maki-Hokkonen, J., Partap, T. (Eds.). Contribution of livestock to mountain livelihoods; research and development issues international centre for integrated mountain development (ICIMODD), pp.3-31

Uddin, M.N., Quaddus, M. 2010. Inter-firm relationships and performance factors in the Australian beef supply chain: implications for the stakeholders. Paper presented at AARES (Australian Agricultural and Resource Economic Society) National Conference, Melbourne

USDA. 2013. Program and Surveys. National Agricultural Statistics Service. United States Department of Agriculture. Available at www.nass.usda.gov. Accessed at May 19th 2013

Van Groningen, Devitt, C. J. B., Wilton, J. W., Cranfield, J.A.L. 2006. Economic evaluations of beef bulls in an integrated supply chain. Journal of Animal Science, Num 84. 